the main major habitats of the world-the sea and its various sub-divisions, the fresh waters, grasslands, desert, forest and so on. In each section he considers the physical characteristics which limit the animal and plant community which has developed and, at the same time, the way in which the latter has evolved to exploit the potentialities of the environment to the full. In his survey he comments on the effects of man on these communities, and in his final chapters points out the cumulative impact of man's activity upon the world as a whole. The horrifying nature of the degradation and imbalance produced is all the more impressively conveyed through being unfolded, step by step, in this way, and in such restrained and objective language.

This particular combination of outstanding photographs, well chosen and reproduced, with an informed and thoughtful textual survey, can put a complete and vivid record of the world's habitats and animals into our hands. We cannot now say we do not know what we are losing.

\title{
H. N. SOUTHERN
}

\section{Charles Darwin. Evolution by Natural Selection. By Sir Gavin de} Beer. British Men of Science Series. Vol. 1. Nelson, 21s.

\section{Biologist and Philosopher. A Study of the Life and Writings of} Alfred Russel Wallace. By Wilma George. Abelard-Schuman, 25s.

The names of Darwin and Wallace will always be associated in histories of the revolution in scientific thought begotten of these two men in midnineteenth century, yet Darwin's fame has far surpassed Wallace's. The story of the Linnean Society's meeting in 1858 has often been told, when their two separate statements of the idea of natural selection were jointly read and subsequently published, to be followed by an enduring friendship and mutually generous acknowledgment of the other's work. Of actual priority there was never any question: Darwin's Linnean contribution dated back fourteen years ; Wallace's share came direct from Ternate in the Moluccas, where during an attack of fever in 1858, the idea of natural selection had dawned on him-" Then it suddenly flashed upon me that this self-acting process would necessarily improve the race, because in every generation the inferior would inevitably be killed off and the superior would remain-that is, the fittest would survive." Wallace followed Herbert Spencer in this tautology.

Has posterity adjudicated fairly in the last hundred years? These two volumes give readers an admirable opportunity to judge for themselves. Sir Gavin de Beer's book is intended for the wide public who need up-todate information on the great minds that have changed current beliefs. His researches into Darwin's previously unpublished early note-books, give him, with his many other qualifications, a pre-eminent authority in tracing the genesis and growth of Darwin's ideas ; he describes with a deep understanding the searching, self-critical, theory-building quality of Darwin's thought. So that when Wallace's letter to Darwin in 1858 fired Darwin to immediate publication, halting him in his longer work already in hand, and compelling him to focus his whole attention on convincing the world in as short a volume as he could compass, that evolution was a universal force through the mediation of natural selection, we can understand how the condensed arguments and frankly faced difficulties compelled immediate attention. Wallace as midwife to the birth of "The Origin" has a unique place in the literary history of evolution quite apart from his own achievements.

Wilma George, lecturer and tutor in zoology, writer on genetics and 
animal geography, has given an informed basis for a judgment on Wallace's place amongst nineteenth-century biologists. Her book should send many readers back to the sources to realise and enjoy Wallace's fertility of mind. The chapters on geographical distribution of animals and on island life should dispel any doubts as to Wallace's greatness. In 1880 it was no commonplace to insist on an ecological outlook. Wallace wrote of the " complete interdependence of organic and inorganic nature...". Wallace's mind was quick, intuitive, perceptive, but the drive of experimental verification was absent. He wrote about the significance of Douglas Spalding's early work on what is now termed imprinting in young chicks and ducklingsnot mentioned by Wilma George. He possessed this primary asset of perceiving the significant, but he was not dogged in following the track. To readers of ORYX, the story of collectors of specimens of more than a hundred years ago has a special meaning. Museums had to be stocked for the increase of knowledge ; but Wallace's collections were already going to rich private collectors, the forerunners of the spoliators of today. Wallace had to reach his ambition of travel and scientific discovery the hard way. Money was short ; he, like Darwin, was often ill, and a dramatic ship-wreck ruined many of his spoils. Darwin was well-off, and the chance to travel the world as naturalist came unasked. But it was the ordered use of his opportunities that counted.

NORA BARLOW

\section{The Life of Birds. By Joel Carl Welty. Constable, 84s.}

In his opening paragraphs the author, a Professor of Zoology at Beloit College, Wisconsin, U.S.A., informs his readers that his book is directed to the general student, and not towards the specialist. Even if that be granted, a survey of the twenty-three chapter-headings should convince the specialist that he can ill afford to neglect its pages, for here, gathered under one cover, is an encyclopaedia of specialised knowledge, covering, as the title claims, the life of birds. In addition to discussing the more ordinary subjects such as social behaviour, territory, nests, eggs, incubation and so on, Dr. Welty has much to tell us concerning courtship, ecology, geography, migration, orientation and evolution, all of which and many other subjects besides, he deals with in an agreably lucid manner, shunning, as he is careful to state, all technicalities which can be avoided. The result is a thoroughly readable compilation. At the end of the book he sets out in alphabetical sequence the names of those authors to whose writings he is particularly indebted, and when we consider that "about 800 seemed important enough to merit special mention ", the extent of his reading will be understood. More than on any other author Dr. Welty has relied upon that remarkable work Aves by Professor Erwin Stresemann, an outstanding contribution to ornithological science, and one that is all too little known in Great Britain. It is written in German which is undoubtedly the cause.

In his preface the author deplores that-in America-societies for bird study are relegated to a lower caste than those devoted to the study of fishes, reptiles, mammals, insects and even microscopic protozoa ; for years " bird researchers" have been treated as second-rate scientists " not worthy of the rank in academic peck order that is accorded even to a specialist in tapeworms." That to a great extent was true in our own country, but those days are fast drawing to a close and books such as Aves to which Dr. Welty has paid such high tribute, and now his own more popular treatise, go far to prove that ornithologists, to whatever country they belong, will soon be in the very front rank in zoological science, if indeed they are not already there. 